\title{
Interleukin Inhibitor
}

National Cancer Institute

\section{Source}

National Cancer Institute. Interleukin Inhibitor. NCI Thesaurus. Code C124064.

Any agent that inhibits the action of an interleukin. These agents inhibit various immune functions. 